\title{
Trace Element Analysis in Some Plants Species by Inductively Coupled Plasma Optical Emission Spectrometry (ICP-OES)
}

\author{
Ismail YENER ${ }^{1 *}$
}

\begin{abstract}
In this study, the whole parts of eight edible and medicinal species (Alcea rosea, Carduus pycnocephalus subsp. albidus, Euphorbia gaillardotii, Euphorbia macroclada, Hypericum triquetrifolium, Kickxia lanigera, Malvella sherardiana and Mentha longifolia subsp. noeana were determined for their trace element ( $\mathrm{Al}, \mathrm{As}, \mathrm{B}, \mathrm{Cd}, \mathrm{Cr}, \mathrm{Cu}, \mathrm{Fe}, \mathrm{Mn}, \mathrm{Ni}, \mathrm{Pb}$ and $\mathrm{Se}$ ) contents using ICP-OES. Before the whole plant parts were analyzed by ICP-OES, the porcelain crucibles were ashed and dissolved by adding concentrated nitric acid and hydrogen peroxide. The accuracy of the method was assessed by NCS ZC73014 Tea Leaves. The trace element contents obtained from each samples were compared. Calibration curves had good linearity in the concentration ranges $0.05-1.5 \mathrm{mg} \mathrm{L}^{-1}$ for whole elements worked. Since correlation coefficient $(\mathrm{R})$ values were found above 0.9997, the linear range was considered acceptable. When the studied species are compared in terms of their metal contents; $\mathrm{Cd}\left(0.41 \pm 0.02 \mathrm{mg} \mathrm{kg}^{-1}\right)$ and $\mathrm{Cu}\left(13.9 \pm 0.9 \mathrm{mg} \mathrm{kg}^{-1}\right)$ metals in Carduus pycnocephalus subsp. albidus, B $\left(22.4 \pm 1.6 \mathrm{mg} \mathrm{kg}^{-1}\right)$ metal in Euphorbia macroclada, Se $\left(0.26 \pm 0.01 \mathrm{mg} \mathrm{kg}^{-1}\right)$ metal in Hypericum triquetrifolium Al (1424 $\left.\pm 109 \mathrm{mg} \mathrm{kg}^{-1}\right), \mathrm{Cr}\left(4.8 \pm 0.2 \mathrm{mg} \mathrm{kg}^{-1}\right), \mathrm{Fe}\left(980 \pm 67 \mathrm{mg} \mathrm{kg}^{-1}\right) \mathrm{Mn}$ $\left(44.6 \pm 2.4 \mathrm{mg} \mathrm{kg}^{-1}\right) \mathrm{Ni}\left(7.5 \pm 0.3 \mathrm{mg} \mathrm{kg}^{-1}\right)$ and $\mathrm{Pb}\left(1.15 \pm 0.1 \mathrm{mg} \mathrm{kg}^{-1}\right)$ metals in Malvella sherardiana, As $\left(0.62 \pm 0.02 \mathrm{mg} \mathrm{kg}^{-1}\right)$ metals in Mentha longifolia subsp. noeana were determined higher. While the toxic element $(\mathrm{As}$ and $\mathrm{Pb}$ ) content of the studied species is low compared to $\mathrm{WHO}, \mathrm{Cd}$ and $\mathrm{Cr}$ contents in some species are found to be high to WHO.
\end{abstract}

Keywords: Some Edible Plants, Trace Element, ICP-OES, Metal

\section{Bazı Bitki Türlerinde İndüktif Eşleşmiş Plazma Optik Emisyon Spektrometresi (ICP-OES) ile Eser Element Analizi}

ÖZET: Bu çalışmada Türkiye'nin Diyarbakır ve Mardin illerinde toplanmış, halk arasında yaygın olarak bitki çayı ve tibbi bitki olarak kullanılan Alcea rosea, Carduus pycnocephalus subsp. albidus, Euphorbia gaillardotii, E. macroclada, Hypericum triquetrifolium, Kickxia lanigera, Malvella sherardiana and Mentha longifolia subsp. noeana türlerinin ICP-OES tekniği ile (Al, $\mathrm{As}, \mathrm{B}, \mathrm{Cd}, \mathrm{Cr}, \mathrm{Cu}, \mathrm{Fe}, \mathrm{Mn}, \mathrm{Ni}, \mathrm{Pb}$ and $\mathrm{Se}$ ) eser element içeriği tayin edilmiştir. Türlerin tüm parçalarından oluşan örnekler ICP-OES ile analiz edilmeden önce porselen krozelerde kül edildilerek üzerine derişik nitrik asit ve hidrojen peroksit ilave edilerek hzırlanmıştır. Standart referans madde olarak NCS ZC73014 Çay Yaprağı kullanılarak metodun doğruluğu belirlenmiştir. Çalışılan tüm elementler için kalibrasyon eğrileri $0.05-1.5 \mathrm{mg} \mathrm{L}^{-1}$ konsantrasyon aralığında iyi doğrusallığa sahip olduğu belirlenmiştir. Korelasyon katsayısı (R) değerleri 0.9997 ' nin üzerinde olduğundan, doğrusal aralık kabul edilebilir olarak değerlendirilmiştir. Çalışılan her türün eser element içeriği bir biriyle karşılaştırılmıştır. Yapılan kıyaslamada; Carduus pycnocephalus subsp. albidus, türünde $\mathrm{Cd}\left(0.41 \pm 0.02 \mathrm{mg} \mathrm{kg}^{-1}\right)$ ve Cu $\left(13.9 \pm 0.9 \mathrm{mg} \mathrm{kg}^{-1}\right)$, Euphorbia macroclada türünde B $\left(22.4 \pm 1.6 \mathrm{mg} \mathrm{kg}^{-1}\right)$, Hypericum triquetrifolium, Se $\left(0.26 \pm 0.01 \mathrm{mg} \mathrm{kg}^{-1}\right)$, Malvella sherardiana türünde $\mathrm{Al}\left(1424 \pm 109 \mathrm{mg} \mathrm{kg}^{-1}\right), \mathrm{Cr}\left(4.8 \pm 0.2 \mathrm{mg} \mathrm{kg}^{-1}\right), \mathrm{Fe}\left(980 \pm 67 \mathrm{mg} \mathrm{kg}^{-1}\right) \mathrm{Mn}(44.6 \pm 2.4$ $\left.\mathrm{mg} \mathrm{kg}{ }^{-1}\right) \mathrm{Ni}(7.5 \pm 0.3 \mathrm{mg} \mathrm{kg})$ ve $\mathrm{Pb}\left(1.15 \pm 0.1 \mathrm{mg} \mathrm{kg}^{-1}\right)$, Mentha longifolia subsp. noeana türünde As $\left(0.62 \pm 0.02 \mathrm{mg} \mathrm{kg}^{-1}\right)$ içeriği daha yüksek olduğu belirlenmiştir. Çalış1lan türlerin toksik element (As ve $\left.\mathrm{Pb}\right)$ içeriğinin WHO'ya göre düşük bulunurken, bazı türlerde $\mathrm{Cd}$ ve $\mathrm{Cr}$ içerikleri ise yüksek olduğu tespit edilmiştir.

Anahtar Kelimeler: Bazı Yenilebilen Bitkiler, Eser Element, ICP-OES, Metal

\footnotetext{
${ }^{1}$ Ismail YENER (Orcid ID: 0000-0002-0988-9462), Dicle University, Faculty of Pharmacy, Department of Analytical Chemistry, Diyarbakir, Turkey

* Sorumlu Yazar/Corresponding Author: Ismail YENER, e-mail: ismail.yener@dicle.edu.tr 


\section{INTRODUCTION}

Medicinal and edible plants are materials that have demonstrated biological activity and used in the treatment of various diseases among people since ancient times (Ertas et al., 2015a; Ertas et al., 2015b). Trace elements play an important role in the formation of active chemicals in medicinal plants and are also responsible for the toxicity of medicinal plants (Abugassa et al., 2008). Physiological activities of twenty-three elements in humans and other mammals are known (Karadas and Kara, 2012). Some of these elements ( $\mathrm{Zn}, \mathrm{Fe}, \mathrm{Cu}, \mathrm{Cr}$ and $\mathrm{Co}$ ) need to be taken for certain levels and their toxic effects occur only at very high levels. $\mathrm{Hg}, \mathrm{Pb}$ and $\mathrm{Cd}$ show toxic effects on any levels have been known no beneficial properties. Metal ions in the chemical components of plants determine the medicinal, nutritious and toxic properties of the plant (Tokalıoglu, 2012). Some medicinal plants and their mixtures may cause health risks owing to their toxic element contents. In particular, toxic effects are caused by heavy metal poisoning (Basgel ve Erdemoglu, 2006). Generally, $\mathrm{Pb}$ in medicinal plants and spices, $\mathrm{Cd}$ in food are commonly caused by environmental pollution. High levels of As can be caused by the use of pesticides and fertilizers (Giacomino et al., 2015). The quantification of some trace elements is important for the treatment of various diseases and for determining the effects of medicinal plants and to understand the pharmacological effects of their and to determine the dosage of herbal medicines formed from medicinal plants (Abugassa et al., 2008; Nookabkaew et al., 2006). Plants are an important way of transition of trace elements from soil to man (Bin et al., 2001). Therefore; Quality control of the trace element content of medicinal plants is important.

The Euphorbiaceae is a large family of the flowering plants that includes 300 genera and over 5.000 species ranging from annuals to trees
(Webester, 1994). Euphorbia is one of the largest genuses which belongs to Euphorbiaceae family, and represented by 105 species in Turkey (Oztekin et al., 2012). Euphorbia species are named as "Sütleğen and Xaşîl" (Baytop, 1984; Firat, 2013), Euphorbia macroclada and Euphorbia gaillardotii are mostly used in Turkish folk medicine for the treatment of rheumatism, swelling, as well as a wart remover. However, inflamation and diarrhea are the two potential side effects that might occur during the treatment (Baytop, 1984).

The genera Alcea and Malvella are belong to Malvaceae family. Malvaceae family plants are exceptional among leafy plants due to their high content of polyprenols, which are chemotaxonomic markers (Matthaus et al., 2003; Khidyrova et al., 2012). Genus Alcea are represented by about 70 species worldwide, distributing in Mediterranean and Iran-Turanian phytogeographical region (Baytop, 1999; Turkoglu, 2000). In Turkey, the genus Alcea is represented by 20 species which are called Hatmi (Gencay, 2007), in general. Genus Malvella is represented by 1 species in Turkey (Davis, 1966) and represented by 4 species in world. Malvella sherardiana is distributed from Europae to Caucasia and Syria. Its local names are Ebekömeci, Ebemkömeci, Ebemgömeci. Leaves and flowers are used as food and used for treatment of kidney disease and constipation (Baytop, 1999; Akaydın et al., 2013).

The Mentha species (Lamiaceae family) widely distributed in Euroasia, Australia and South Africa have been grown in damp or wet places (Gulluce et al., 2007). The leaves, flowers and stems of the Mentha species have been used as carminative, antispasmodic, antiemetic, stimulant, analgesic, and emmenagogue in traditional medicine all around the world. Their leaves have been also consumed as herbal tea and spice (Iscan et al., 2002)

The genus Hypericum a member of Hypericaceae family is represented by 100 taxa, 45 being endemic to Turkey (Robson, 1988; 
Ozhatay et al., 2011). In Turkish folk medicine, the genus Hypericum is known as "Sarı Kantaron, Kantaron, Binbirdelik Otu, Mayasıl Otu" and most of them, especially $H$. perforatum, have been used for the treatment of burns, wounds, hemorroids, diarrhea and ulcers (Baytop, 1984). Aqueous extracts of the flowering aerial parts of the Hypericum species are used in the treatment of neuralgia, anxiety, neurosis and depression (Blumenthal et al., 2000).

Cardaria draba subsp. draba and Carduus pycnocephalus subsp. abidus are used as vegetable in southeastern part of Turkey. Root and aerial parts of $S$. hispanicus and infusion of Cardaria species used as diuretic and for kidney and gall stone. Decoction of Carduus species is used as appetizer and for antidiabetic (Baytop, 1999).

Kickxia is a genus of plants in the Plantaginaceae. It includes several species of plants known commonly as cancerworts or fluellins. They are mostly native to Europe, but two species, $K$. elatine and $K$. spuria are wellknown elsewhere as invasive weeds. Kickxia species have been extensively used for traditional medicine to decrease some lighten such as diuretic, against kidney stones, fever and rheumatism (Dumort, 2018).

Trace elements play a significant role in the formation of chemical constituents in plants (Abugassa et al., 2008). It is known that twentythree elements have physiological activities in mammals (Karadas and Kara, 2012). Some metals, such as, zinc, iron, copper, chromium and cobalt, are necessary at certain levels and they are toxic in high concentrations. On the other hand, some other metals; namely, mercury, lead and cadmium, are toxic even at low concentrations and have been known no useful properties. Determining of metal ion composition of plants support their medicinal nutrient and/or toxic properties (Tokalioglu, 2012).

Trace elements have important roles in plant metabolism and biosyntheses as cofactors for the enzymes. Medicinal plants are widely used in the treatment of human diseases and pain relief, due to their low adverse effects. Some medicinal plants and their mixtures may pose health risks owing to toxic elements contain. The contamination may become from the environmental pollution (Basgel, and Erdemoglu, 2006). For example, high levels of arsenic can result from the use of pesticides and fertilizers (Giacomino et al., 2015). Human beings need metallic and nonmetallic elements, within the permitted limits, for growth and health. Plants are an important medium for trace elements to transit from the soil to human beings. Accordingly, the quality controls of these medicinal plants are important in terms of trace element content.

In this study, collected from eastern Turkey (Mardin and Diyarbakir) that comestible and medicinal using species determine toxic and nutrient elements concentrations by using ICPOES.

\section{MATERIAL AND METHODS}

\section{The Plant Materials}

We collected the whole plant parts of Alcea rosea L., Carduus pycnocephalus L. subsp. albidus, Euphorbia gaillardotii Boiss., E. macroclada Boiss., Hypericum triquetrifolium Turra., Kickxia lanigera Desf., Malvella sherardiana L. and Mentha longifolia L. Hudson subsp. noeana species from southeast of Turkey in July 2015 by Dr. Abdulselam Ertas, Mehmet Firat and Yeter Yesil. They were identified by Mehmet Firat and Yeter Yesil Voucher specimens have been strored in the Herbarium of Yuzuncu Yil University and in the Herbarium of Istanbul University (Table 1 and Figure 1). 
Table 1. Collection places, time of gathering and herbarium records of species

\begin{tabular}{llll}
\hline Plant name & Collection location & Collection time & Herbarium number \\
\hline A. rosea & Mardin & July 2015 & Y. Yesil 97149(ISTE) \\
C. pycnocephalus subsp. albidus & Diyarbakır & July 2015 & Y. Yesil 97145(ISTE) \\
E. gaillardotii & Diyarbakır & July 2015 & M. Firat 30185(VANF) \\
E. macroclada & Diyarbakır & July 2015 & M. Firat 30186(VANF) \\
H. triquetrifolium & Diyarbakır & July 2015 & Y. Yesil 98926(ISTE) \\
K. lanigera & Diyarbakır & July 2015 & Y. Yesil 98927(ISTE) \\
M. sherardiana & Diyarbakır & July 2015 & Y. Yesil 98928(ISTE) \\
M. longifolia subsp. noeana & Mardin & July 2015 & Y. Yesil 83521(ISTE) \\
\end{tabular}

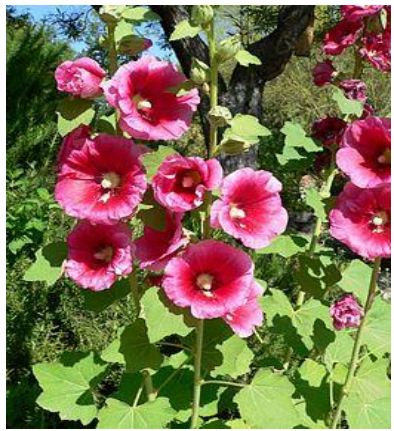

A. rosea

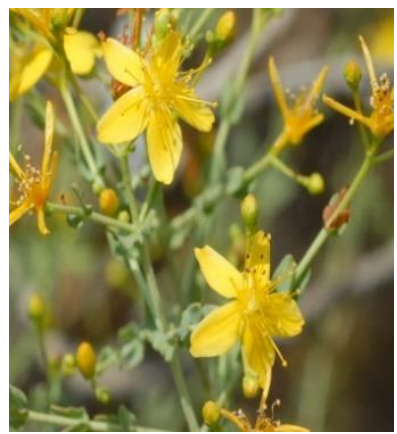

H. triquetrifolium

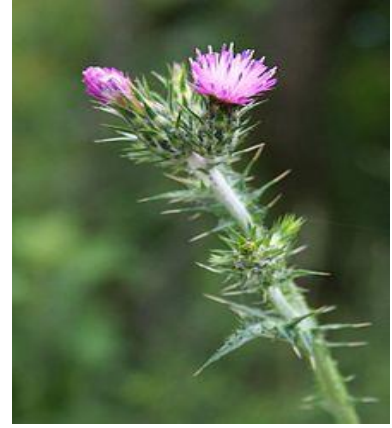

C. pycnocephalus subsp. albidus

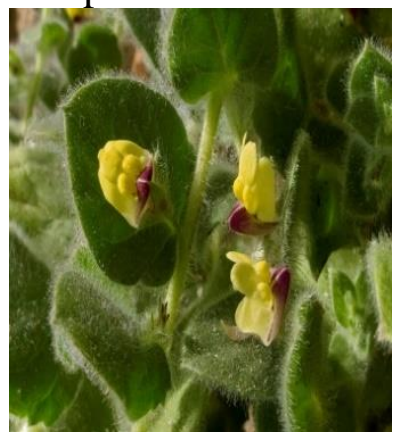

K. lanigera

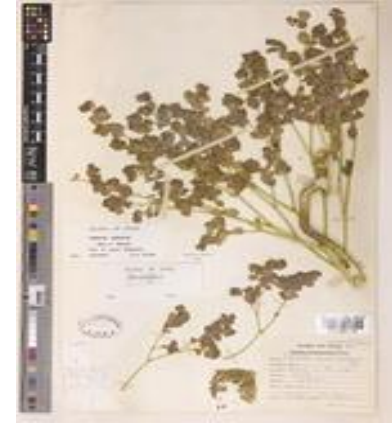

E. gaillardotii

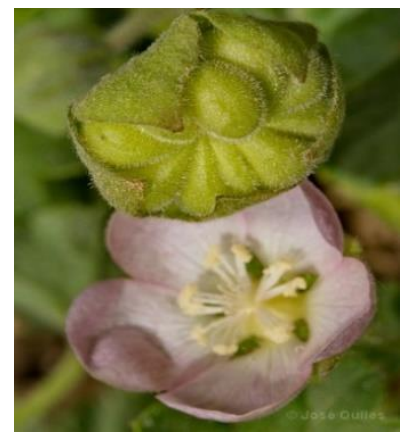

M. sherardiana

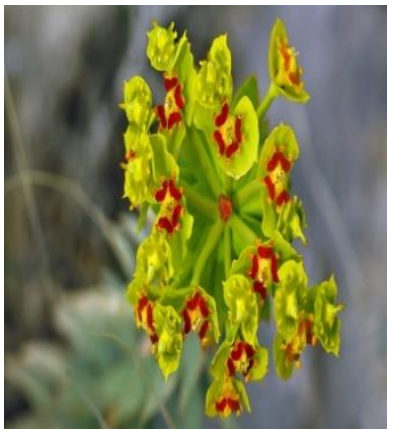

E. macroclada

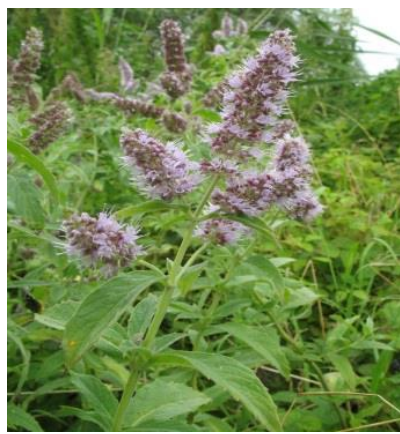

M. longifolia subsp. noeana

Figure 1. Investigated species

\section{Instruments}

A Perkin Elmer Optima 2000 DV model ICP-OES was used to determine $\mathrm{Al}, \mathrm{As}, \mathrm{B}, \mathrm{Cd}$, $\mathrm{Cr}, \mathrm{Cu}, \mathrm{Fe}, \mathrm{Ni}, \mathrm{Pb}$ and $\mathrm{Se}$ in the samples. The operating conditions for the ICP-OES are shown in Table 2.

\section{Digestion of the Samples}

By grouping the samples, washed by tap water first and deionized water secondly, and dried at $70{ }^{\circ} \mathrm{C}$ ' for 48 hours. The dried samples were then pulverized by a blender. Plant samples (whole plant parts) were prepared by ashing method. Approximately $2.5 \mathrm{~g}$ of powdered samples were weighed and placed into porcelain crucibles for ashing procedure. Then the samples burned gradually with 105, 150, 270 and $570{ }^{\circ} \mathrm{C}$ emperatures and kept for 4 hours at the final temperature. $5.0 \mathrm{~mL}$ of $\mathrm{HCl}: \mathrm{HNO}_{3}: \mathrm{H}_{2} \mathrm{O}_{2}(1: 3: 1$ $\mathrm{v} / \mathrm{v})$ mixture was added 2 times on the samples became to ashes and evaporated to dryness. The residue was centrifuged after dissolving in 10.0 $\mathrm{mL}$ 1.0 $\mathrm{M} \mathrm{HNO}_{3}$. And finally the concentrations of $\mathrm{Al}, \mathrm{As}, \mathrm{B}, \mathrm{Cd}, \mathrm{Cr}, \mathrm{Cu}, \mathrm{Fe}, \mathrm{Mn}, \mathrm{Ni}, \mathrm{Pb}$ and $\mathrm{Se}$ in the samples were determined by ICP-OES. 


\section{Reagents and Solutions}

The deionized water (18.2 $\mathrm{M} \Omega$ ) was used in all experiments. Nitric acid (Merck) and hydrogen peroxide (Merck) with analytical purity were used in the digestion processes.

The accuracy and precision of the method were evaluated using certified reference material NCS ZC73014 Tea leaves (National Institute of Standards and Technology, NIST, Gaithersburg, MD, USA).

In the ICP-OES measurements, Al, As, B, $\mathrm{Cd}, \mathrm{Cr}, \mathrm{Cu}, \mathrm{Fe}, \mathrm{Mn}, \mathrm{Ni}, \mathrm{Pb}$ and $\mathrm{Se}$ were used as the mix standard $\left(1000 \mathrm{mg} \mathrm{L}^{-1}\right)$. The calibration standard solutions $\left(0.05-1.5 \mathrm{mg} \mathrm{L}^{-1}\right)$ used were prepared by appropriate dilution of the stock mix standards $\left(10 \mathrm{mg} \mathrm{L}^{-1}\right)$.
The linear range, regression and correlation coefficient (R) values, limit of detection (LOD), limit of quantification (LOQ), which belong to the calibration chart drawn under the optimal operating conditions for eleven elements, are shown in Table 3. Coefficient $(\mathrm{R})$ values are higher than 0.999 . Therefore, the linearity was evaluated as acceptable. The LOD and LOQ values for eleven metals were calculated using 3 independent blank solutions. The LOD and LOQ were found to be $3 . \sigma$ and $10 . \sigma$, respectively.

The accuracy of the method is evaluated using certified reference material NCS ZC73014 Tea Leaves. The results of certified reference material NCS ZC73014 Tea Leaves are given in Table 4.

\section{Method Validation}

Table 2. working conditions conditions of the ICP-OES. (Ozdemir et. al. 2009)

\begin{tabular}{ll}
\hline Parameter & \\
\hline RF power $(\mathrm{W})$ & 1450 \\
Plasma gas flow rate $(1 / \mathrm{min})$ & 15 \\
Auxiliary gas flow rate $(1 / \mathrm{min})$ & 0.2 \\
View mode & Axial-radial \\
Sample flow rate $(1 / \mathrm{min})$ & 1.5 \\
Nebulizer gas flow rate $(1 / \mathrm{min})$ & 0.9 \\
Read delay (s) & 60 \\
Read & Peak area \\
Source equilibration time $(\mathrm{s})$ & 15 \\
Replicates & 3 \\
Nebulizer & Cross-Flow GemTip Nebulizer (HF resistant) \\
Purge gas & Nitrogen \\
Shear gas & Air \\
Gas & Argon \\
\hline & Cu 327.393 \\
Analytical wavelengths $(\mathrm{nm})$ & Ni 231.604 \\
& Cd 228.802 \\
& Mn 257.610 \\
\hline
\end{tabular}

Table 3. Analytical parameters of the ICP-OES

\begin{tabular}{lllrrr}
\hline Element & Linear range $\left(\mathbf{m g L}^{-\mathbf{1}}\right)$ & \multicolumn{1}{c}{ Regression } & $\mathbf{R}^{\mathbf{2}}$ & LOD $\left(\mathbf{m g L}^{-\mathbf{1}}\right)$ & $\left.\mathbf{L O Q}_{(\mathbf{m g L}} \mathbf{- 1}^{\mathbf{1}}\right)$ \\
\hline $\mathrm{Al}$ & $0.05-1.5$ & $\mathrm{y}=240100 \mathrm{x}+392$ & 0.9999 & 0.048 & 0.144 \\
$\mathrm{As}$ & $0.05-1.5$ & $\mathrm{y}=404.4 \mathrm{x}+8$ & 0.9997 & 0.021 & 0.063 \\
$\mathrm{~B}$ & $0.05-1.5$ & $\mathrm{y}=43840 \mathrm{x}+194$ & 0.9999 & 0.130 & 0.390 \\
$\mathrm{Cd}$ & $0.05-1.5$ & $\mathrm{y}=57820 \mathrm{x}-239$ & 0.9999 & 0.019 & 0.057 \\
$\mathrm{Cr}$ & $0.05-1.5$ & $\mathrm{y}=42760 \mathrm{x}-32$ & 0.9999 & 0.041 & 0.123 \\
$\mathrm{Cu}$ & $0.05-1.5$ & $\mathrm{y}=162100 \mathrm{x}+411$ & 0.9999 & 0.072 & 0.216 \\
$\mathrm{Fe}$ & $0.05-1.5$ & $\mathrm{y}=53130 \mathrm{x}+296$ & 0.9999 & 0.123 & 0.369 \\
$\mathrm{Mn}$ & $0.05-1.5$ & $\mathrm{y}=448800 \mathrm{x}+953$ & 0.9999 & 0.062 & 0.186 \\
$\mathrm{Ni}$ & $0.05-1.5$ & $\mathrm{y}=14860 \mathrm{x}-7$ & 0.9999 & 0.030 & 0.090 \\
$\mathrm{~Pb}$ & $0.05-1.5$ & $\mathrm{y}=2601 \mathrm{x}+2$ & 0.9999 & 0.051 & 0.153 \\
$\mathrm{Se}$ & $0.05-1.5$ & $\mathrm{y}=494.3 \mathrm{x}+2$ & 0.9999 & 0.031 & 0.093 \\
\hline
\end{tabular}


Table 4. Accuracy evaluation of analysis of NCS ZC73014 Tea leaves

\begin{tabular}{llll}
\hline Metals & Certified $\left(\mathbf{m g ~ k g}^{-1}\right)$ & Found $\left(\mathbf{m g ~ k g}^{-1}\right)$ & Recovery $(\%)$ \\
\hline $\mathrm{Al}$ & - & - & \\
$\mathrm{As}$ & $0.09 \pm 0.01$ & $0.09 \pm 0.02$ & 100 \\
$\mathrm{~B}$ & $14 \pm 1$ & $13 \pm 1$ & 93 \\
$\mathrm{Cd}$ & $0.062 \pm 0.004$ & $0.060 \pm 0.004$ & 97 \\
$\mathrm{Cr}$ & $0.45 \pm 0.10$ & $0.42 \pm 0.10$ & 93 \\
$\mathrm{Cu}$ & $18.6 \pm 0.7$ & $18.0 \pm 0.5$ & 97 \\
$\mathrm{Fe}$ & $242 \pm 18$ & $233 \pm 21$ & 96 \\
$\mathrm{Mn}$ & $500 \pm 20$ & $490 \pm 17$ & 98 \\
$\mathrm{Ni}$ & $3.4 \pm 0.3$ & $3.2 \pm 0.4$ & 94 \\
$\mathrm{~Pb}$ & $1.5 \pm 0.2$ & $1.4 \pm 0.2$ & 93 \\
$\mathrm{Se}$ & $0.098 \pm 0.008$ & $0.099 \pm 0.004$ & 101 \\
\hline
\end{tabular}

\section{RESULTS AND DISCUSSION}

When the study is examined in terms of the amount of aluminum element, it is seen that the results of the studied species are variable. In our study; Al contents of examined plants are seen as $A$. rosea $<E$. gaillardotii $<E$. macroclada $<H$. triquetrifolium $<K$. lanigera $<C$. pycnocephalus subsp. albidus $<M$. longifolia subsp. noeana $<M$. sharardiana in the order of an increase.

In a study by Varhan Oral et. al., (2018) they determined that the As content in the edible Allium species (from collected East Anatolia) were in the range of $0.013-0.325 \mathrm{mg} \mathrm{kg}^{-1}$. Then in our study As contents were found as $H$. triquetrifolium $<A$. rosea $C$. pycnocephalus subsp. albidus $<$ E.gaillardotii $<K$. lanigera $<E$. macroclad $a<M$. sharardiana $<M$. longifolia subsp. noeana in the order of an increase. And also, some species contents were found to exceed the reference value for As. Therefore, it is important to pay attention to the amount of consumed for these species.

In our study, the amount of boron varies in the range $9.5-22.4 \mathrm{mg} \mathrm{kg}^{-1}$. According to the results, chrome content was determinated lowest in A. rosea and then highest in E. macroclada species.

In a study conducted by Saglam, Cd accumulation in plants was found to be above normal value $\left(0.25 \mathrm{mg} \mathrm{kg}^{-1}\right)$. In our study the amount of cadmium in the studied species show variabilites. In addition, it was determined that the lowest $\mathrm{Cd}$ amount $\left(0.08 \pm 0.003 \mathrm{mg} \mathrm{kg}^{-1}\right)$ was found in $A$. rosea and also the highest $\mathrm{Cd}$ amount $\left(0.41 \pm 0.02 \mathrm{mg} \mathrm{kg}^{-1}\right)$ was found in $C$. pycnocephalus subsp. albidus. And also, it was found that some species exceeded the reference value in terms of As content. Therefore, it is important to pay attention to the consumption amounts in these species.

According to WHO data, there are no acceptable limit values for $\mathrm{Cr}$ element. In the study by Rai et. al., (2005) the amount of chromium varies in the range $0.15-4.8 \mathrm{mg} \mathrm{kg}^{-1}$. In our study chrome contents of eight edible plants were measured. According to our findings, chrome content was determinated lowest in $A$. rosea and then highest in $M$. sharardiana species.

The concentration of trace elements of some medicinal plants species are presented in Table 5.

When the study is examined in terms of the amount of aluminum element, it is seen that the results of the studied species are variable. In our study; Al contents of examined plants are seen as $A$. rosea $<E$. gaillardotii $<E$. macroclada $<H$. triquetrifolium $<K$. lanigera $<C$. pycnocephalus subsp. albidus $<M$. longifolia 
subsp. noeana $<M$. sharardiana in the order of an increase.

In a study by Varhan Oral et. al., (2018) they determined that the As content in the edible Allium species (from collected East Anatolia) were in the range of $0.013-0.325 \mathrm{mg} \mathrm{kg}^{-1}$. Then in our study As contents were found as $H$. triquetrifolium $<A$. rosea $<$. pycnocephalus subsp. albidus $<$ E.gaillardotii $<K$. lanigera $<E$. macroclada $<M$. sharardiana $<M$. longifolia subsp. noeana in the order of an increase. And also, some species contents were found to exceed the reference value for As. Therefore, it is important to pay attention to the amount of consumed for these species.

In our study, the amount of boron varies in the range $9.5-22.4 \mathrm{mg} \mathrm{kg}^{-1}$. According to the results, chrome content was determinated lowest in A. rosea and then highest in E. macroclada species.

In a study conducted by Saglam, Cd accumulation in plants was found to be above normal value $\left(0.25 \mathrm{mg} \mathrm{kg}^{-1}\right)$. In our study the amount of cadmium in the studied species show variabilites. In addition, it was determined that the lowest $\mathrm{Cd}$ amount $\left(0.08 \pm 0.003 \mathrm{mg} \mathrm{kg}^{-1}\right)$ was found in $A$. rosea and also the highest $\mathrm{Cd}$ amount $\left(0.41 \pm 0.02 \mathrm{mg} \mathrm{kg}^{-1}\right)$ was found in $C$. pycnocephalus subsp. albidus. And also, it was found that some species exceeded the reference value in terms of As content. Therefore, it is important to pay attention to the consumption amounts in these species.

According to WHO data, there are no acceptable limit values for $\mathrm{Cr}$ element. In the study by Rai et. al., (2005) the amount of chromium varies in the range $0.15-4.8 \mathrm{mg} \mathrm{kg}^{-1}$. In our study chrome contents of eight edible plants were measured. According to our findings, chrome content was determinated lowest in A. rosea and then highest in $M$. sharardiana species.
The concentration of trace elements of some medicinal plants species are presented in Table 5.

In a study conducted by Akguc et al., (2010), they found that the normal limits for $\mathrm{Cu}$ in plants were in the range of $4-15 \mathrm{mg} \mathrm{kg}^{-1}$. And also, they stated that copper had toxic effects on human health when the amount of copper was above these values. In our study, it was determined that the $\mathrm{Cu}$ content of the studied species was observed differently and was below the specified limit values.

In addition, the $\mathrm{Cu}$ amount of studied species are lower than the limit value determined by WHO.

In a study by Hajar et. al. (2014), Fe metal content in edible plants (640-2486.4 $\mathrm{mg} \mathrm{kg}^{-1}$ ) was determined, and also they described this range as normal. In our study, Fe amounts of edible plants were found to be in this range or lower.

In the study by Hajar et. al. (2014), the contents of $\mathrm{Mn}$ metal were determinated in normal levels in the range of $15-100 \mathrm{mg} \mathrm{kg}^{-1}$ or in the range of $1500-3000 \mathrm{mg} \mathrm{kg}^{-1}$ as in toxic levels. In our study, the amount of Mn varies in the range 5.4- $44.6 \mathrm{mg} \mathrm{kg}^{-1}$. According to the results, Mn content was determinated lowest in A. rosea and then highest in M. sharardiana species.

In addition, when the Mn content of plant species is examined, it is determinated that the contents are in normal levels.

In a study conducted by Ozay ve Mammaadov (2013), they found that the normal limits for $\mathrm{Ni}$ in plants were in the range of 0.5-10 $\mathrm{mg} \mathrm{kg}^{-1}$. When the species studied were evaluated, the $\mathrm{Ni}$ contents were observed below the specified limit value.

In general, nickel content in foods is desired to be less than $0.5 \mathrm{mg} \mathrm{kg}^{-1}$, but in some foods (such as cocoa, soybean) may be higher. Necessary Ni amount may differs between 80- 
$100 \mu \mathrm{g} /$ day for human health. (Ebdon et al., 2001). In our study $\mathrm{Ni}$ contents of examined edible plants are seen as $A$. rosea $<H$. triquetrifolium $<$ E. gaillardotii $<$ E. macroclada $<M$. longifolia subsp. noeana $<C$. pycnocephalus subsp. albidus $=K$. lanigera $<M$. sharardiana in the order of an increase. In the study, the dosage is very important in the consumption of these medicinal and edible species.

A study by Cağlarırmak and Hepçimen (2010) the toxicity of $\mathrm{Pb}$ is investigated. Lead must ascended to a certain level in the blood, to create a toxic effect im the human body. Lead blood concentration shows variabilities depending on many factors like age, nutrition and physiological conditions. Additionally when the blood lead level increases to $100-1000 \mu \mathrm{g} \mathrm{L}^{-1}$ some negative effects may be occur especially on central nervous system and also haematological parameters (WHO, 2001).
According to the US Food and Drug Administration's total diet study, $\mathrm{Pb}$ daily dietary intakes are determinated in adults, infants and children in the period 1979-1988, from about $90 \mu \mathrm{g}$ /day to below $10 \mu \mathrm{g} \mathrm{day}^{-1}$ for adult males, and from about $30 \mu \mathrm{g}$ day $^{-1}$ to below $5 \mu \mathrm{g}$ day $^{-1}$ for infants (Bolger et al., 1991). These daily intake levels are quite low. In our study, the lead contents of $K$. lanigera and $M$. sharardiana species are higher than others and therefore, these species should be consumed carefully for toxicity risks.

Selenium is an essential trace element necessary for people and animals. It has antioxidant, anti-inflammatory, immunological properties and also protective effects against toxic elements, cancer, and heart problems (Chope et al., 2016). In our study, the Se concentrations of plant species diversified between 0.08 and $0.26 \mathrm{mg} \mathrm{kg}^{-1}$.

Table 5. Concentration of metal in dry mass in some palants species ${ }^{\mathrm{a}}\left(\mathrm{mg} \mathrm{kg}^{-1} \pm \mathrm{SD}\right)$

\begin{tabular}{lcccccc}
\hline Sample & Al & As & B & Cd & Cr & Cu \\
\hline A. rosea & $30 \pm 2$ & $0.34 \pm 0.01$ & $9.50 \pm 0.50$ & $0.08 \pm 0.003$ & $0.15 \pm 0.01$ & $6.10 \pm 0.30$ \\
C. pycnocephalus subsp. albidus & $632 \pm 47$ & $0.35 \pm 0.02$ & $19.90 \pm 1.20$ & $0.41 \pm 0.02$ & $2.20 \pm 0.10$ & $13.90 \pm 0.90$ \\
E. gaillardotii & $106 \pm 11$ & $0.39 \pm 0.01$ & $15.1 \pm 0.90$ & $0.24 \pm 0.02$ & $0.53 \pm 0.04$ & $4.30 \pm 0.20$ \\
E. macroclada & $115 \pm 10$ & $0.46 \pm 0.02$ & $22.40 \pm 1.60$ & $0.12 \pm 0.01$ & $0.55 \pm 0.04$ & $3.70 \pm 0.10$ \\
H. triquetrifolium & $161 \pm 12$ & $0.31 \pm 0.02$ & $10.70 \pm 0.90$ & $0.07 \pm 0.005$ & $0.63 \pm 0.04$ & $6.00 \pm 0.30$ \\
K. lanigera & $357 \pm 24$ & $0.42 \pm 0.01$ & $10.50 \pm 0.90$ & $0.26 \pm 0.02$ & $1.50 \pm 0.10$ & $4.60 \pm 0.20$ \\
M. sharardiana & $1424 \pm 109$ & $0.52 \pm 0.02$ & $21.00 \pm 1.10$ & $0.35 \pm 0.02$ & $4.80 \pm 0.20$ & $10.70 \pm 0.80$ \\
M. longifolia subsp. noeana & $709 \pm 56$ & $0.62 \pm 0.02$ & $13.80 \pm 1.00$ & $0.11 \pm 0.01$ & $2.40 \pm 0.20$ & $10.60 \pm 0.90$ \\
\hline
\end{tabular}

*ND: Not detected

${ }^{\mathrm{a}}$ Values are given as the mean and standard deviation of 3 parallel measurements.

Table 5. Concentration of metal in dry mass in some palants $\operatorname{species}^{\mathrm{a}}\left(\mathrm{mg} \mathrm{kg}^{-1} \pm \mathrm{SD}\right)$ (continuation)

\begin{tabular}{lccccc}
\hline Sample & Fe & Mn & Ni & Pb & Se \\
\hline A. rosea & $15 \pm 1$ & $5.40 \pm 0.20$ & $0.68 \pm 0.05$ & $0.22 \pm 0.02$ & $0.09 \pm 0.006$ \\
C. pycnocephalus subsp. albidus & $433 \pm 35$ & $18.90 \pm 1.10$ & $3.30 \pm 0.20$ & $0.69 \pm 0.04$ & ND* \\
E. gaillardotii & $83 \pm 7$ & $7.10 \pm 0.30$ & $1.70 \pm 0.10$ & $0.33 \pm 0.01$ & $0.16 \pm 0.05$ \\
E. macroclada & $95 \pm 7$ & $15.50 \pm 1.20$ & $1.90 \pm 0.10$ & $0.55 \pm 0.03$ & $0.21 \pm 0.01$ \\
H. triquetrifolium & $125 \pm 10$ & $10.90 \pm 0.90$ & $1.20 \pm 0.10$ & $0.39 \pm 0.02$ & $0.26 \pm 0.01$ \\
K. lanigera & $290 \pm 19$ & $12.80 \pm 0.90$ & $3.30 \pm 0.20$ & $1.10 \pm 0.10$ & $0.13 \pm 0.01$ \\
M. sharardiana & $980 \pm 67$ & $44.60 \pm 2.40$ & $7.50 \pm 0.30$ & $1.15 \pm 0.10$ & N.D \\
M. longifolia subsp. noeana & $397 \pm 27$ & $32.70 \pm 2.00$ & $3.20 \pm 0.20$ & $0.74 \pm 0.03$ & $0.08 \pm 0.004$ \\
\hline
\end{tabular}

*ND: Not detected

${ }^{\mathrm{a}}$ Values are given as the mean and standard deviation of 3 parallel measurements. 


\section{CONCLUSION}

In this study, some plant species gathered in the south of Turkey are investigated in terms of the content of certain eleven trace elements. It is very important to determine the trace element content for consumers of these plants, because some of these species are used as medicinal plants and some as food. ICP-OES technique used in trace element analysis is a correct, precise, fast and sensitive method after the preparing process.

In this study, the metal contents of eight different species are determined. When these metal contents are evaluated according to Table 5; $\mathrm{Al}, \mathrm{Cr}, \mathrm{Fe}, \mathrm{Mn}, \mathrm{Ni}$ and $\mathrm{Pb}$ content of the studied species vary between $30-1424,0.15-4.8$, 15-980, 5.4-44.6, 0.68-7.50 and 0.22-1.15 mg $\mathrm{kg}^{-1}$ respectively. The studied species are compared among themselves, $\mathrm{Al}, \mathrm{Cr}, \mathrm{Fe} \mathrm{Mn}, \mathrm{Ni}$ and $\mathrm{Pb}$ metal concentrations of $M$. sharardiana are found higher than other species $\mathrm{Cd}$ (0.07$\left.0.41 \mathrm{mg} \mathrm{kg}^{-1}\right)$ and $\mathrm{Cu}\left(3.7-13.9 \mathrm{mg} \mathrm{kg}^{-1}\right.$ ) metal contents of $C$. pycnocephalus subsp. albidus species are found higher than other species. B metal content $\left(9.5-22.4 \mathrm{mg} \mathrm{kg} \mathrm{kg}^{-1}\right)$ of $E$. macroclada species was determinated higher. Additionally, Se metal content (0.08-0.26 mg kg$\left.{ }^{1}\right)$ of $H$. triquetrifolium species and also As metal (0.31-0.62 $\mathrm{mg} \mathrm{kg}^{-1}$ ) content of $M$. longifolia subsp. has been found higher than other species.

Each country, placed different regions of the world, determined the toxic metal limit values differently in medicinal plants. In the crude medicinal plant samples, the limit values of $\mathrm{Pb}, \mathrm{As}, \mathrm{Cr}$ and $\mathrm{Cd}$ (toxic metals) are reported as $10,5,2$ and $0.3 \mathrm{mg} \mathrm{L}^{-1}$ respectively. And for the processed medicinal herbal products, daily intake limits of $\mathrm{Pb}, \mathrm{As}, \mathrm{Cr}$ and $\mathrm{Cd}$ (toxic metals) are determinated as $0.02,0.02(\mathrm{~Pb}$ and As have

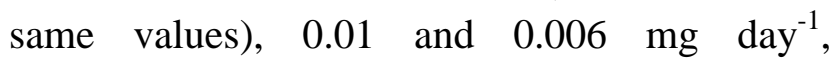
respectively. (WHO: World Health Organization, 1994).
When we look at the useful levels of metals and the toxic limits of these metals for human health, it will be beneficial to use the studied species for food or medical purposes.

Some of the species studied showed that $\mathrm{As}, \mathrm{Pb}$ and $\mathrm{Cd}$ values were lower than the limit values determined for raw medicinal plants, whereas in some species these values were higher. As a result, for the studied species, Alcea rosea, Carduus pycnocephalus subsp. albidus, Euphorbia gaillardotii, E. macroclada, Hypericum triquetrifolium, Kickxia lanigera, Malvella sherardiana and Mentha longifolia subsp. noeana, dosing control is very important in the terms of $\mathrm{As}, \mathrm{Pb}$ and $\mathrm{Cd}$ values. In general, it is recommended that the species used as daily tea or infusion should not be consumed more than a cup in the morning-evening.

\section{ACKNOWLEDGEMENT}

The author wishes express their gratitude to Dr. Mehmet Firat and Dr. Yeter Yesil for helpful assistance in botanical identification.

\section{REFERENCES}

Abugassa I, Bashir A, Doubali K, Etwir R, AbuEnawel M, Abugassa S, 2008. Characterization of trace elements in medicinal herbs by instrumental neutron activation analysis. Journal of Radioanalytical and Nuclear Chemistry, 278(3): 559-563.

Akaydin G, Simsek I, Arituluk ZC, Yesilada E, 2013. An ethnobotanical survey in selected towns of the Mediterranean subregion (Turkey). Turkish Journal of Biology, 37: 230-247.

Akguc N, Ozyigit II, Yasar U, Leblebici Z, Yârci C, 2010. Use of Pyracantha coccinea Roem. as a possible biomonitor for the selected heavy metals, Int. J. Environ. Sci. Tech., 7 (3), 427434.

Basgel S, Erdemoglu SB, 2006. Determination of mineral and trace elements in some medicinal herbs and their infusions consumed in Turkey. Science of the Total Environment 359(1-3): 82-89. 
Baytop T, 1984. Therapy with Medicinal Plants in Turkey, Istanbul University Press, Istanbul, pp. 185.

Baytop T, 1999. Therapy with Plants in Turkey (Past and Present). Publications of Nobel, Istanbul, 337-339.

Bin C, Xiaouru W, Lee, FSC, 2001. Pyrolysis coupled with atomic absorption spectrometry for determination of mercury in Chinese medicinal materials. Anal Chim Acta, 447:161-9.

Blumenthal M, Goldberg A, Brinckmann J, 2000. Integrative medicine communications. Herbal Medicine Newton, pp. 359-366.

Bolger PM., Carrington CD., Capar SG, Adams MA, 1991. Reductions in dietary lead exposure in the United States. Chemical speciation and biovailability, 3(3/4): 31-36).

Chope M, Szczyglowska M, Konieczka P, Namiesnik J, 2016. Methods of selenium supplementation: Bioavailability and determination of selenium compounds. Critical Reviews in Food Science and Nutrition 56 (1):36-55.

Caglarirmak N, Hepcimen AZ, 2010. Effect of Heavy Metal Soil Pollution on Food Chain and Human Health. Review Paper, Akademik Gida, 8 (2): 31-35.

Davis PH, 1996. Flora of Turkey and East Aegean Islands. Vol 2. Edinburgh University Press. Edinburgh.

Dumort K, 2018. Plants of the World Online, Royal Botanic Gardens, Kew, Retrieved 02-03.

Ebdon L, Pitts L, Cornelis R, Crews H, Donard OFX, 2001. Trace Element Speciation for Environment, Food and Health, Royal Society of Chemistry, p: 300.

Ertas A, Boga M, Hasimi N, Yilmaz MA, 2015a. Fatty acid and essential oil compositions of Trifolium angustifoliumvar. angustifoliumwith antioxidant, anticholinesterase and antimicrobialactivities. Iranian Journal of Pharmaceutical Research 14(1): 233-241.
Eras A, Boga M, Yilmaz MA, Yesil Y, Tel G, Temel H, Hasimi N, Gazioglu I, Ozturk M, Ugurlu P, 2015b. A detailed study on the chemical and biological profiles of essential oil and methanol extract of Thymus nummularius (Anzer tea): Rosmarinic acid. Industrial Crops and Products 67: 336-345.

Firat M, 2013. Ferhenga Navên Riwekên Bi Kurdî/Kürtçe Bitki Adları Sözlüğü/Dictionary of Plant Names in Kurdish. Kalkan Ofset, Ankara, 552 pp.

Gencay A, 2007. Ethnobotanical aspects of Cizre (Şırnak), PhD, Institute of Natural and Applied Science, Department of Biology, University of Yüzüncü Yil.

Giacomino A, Abollino O, Casanova C, La Gioia C, Magi E, Malandrino M, 2015. Determination of the total and bioaccessible contents of essential and potentially toxic elements in ayurvedic formulations purchased from different commercial channels. Microchemical Journal 120: 6-17.

Gulluce M, Sahin F, Sokmen M, Ozer H, Daferera D, Sokmen A, Polissiou M, Adiguzel A, Ozkan $\mathrm{H}$, 2007. Antimicrobial and antioxidant properties of the essential oils and methanol extract from Mentha longifolia L. ssp. Longifolia, Food Chem. 103: 1449-1456.

International Programme on Chemical Safety. Assessing human health risks of chemicals: derivation of guidance values for health-based exposure limits. Geneva, World Health Organization, 1994. (Environmental Health Criteria 170.)

Iscan G, Kirimer N, Kurkcuoglu M, Baser KH, Demirci F, 2002. Antimicrobial screening of Mentha piperita essential oils, J. Agric. Food Chem. 50: 3943-46.

Karadas C, Kara D, 2012. Chemometric approach to evaluate trace metal concentrations in some spices and herbs. Food Chemistry 130(1): 196202.

Khidyrova NK, Rakhmatova MZh, Kukina TP, Shakhidoyatov RKh, Shakhidoyatov KhM, 2012. Polyprenols and triterpenoids from leaves of Alcea nudiflora, Chem. Nat. Compd. 48: 180-184. 
Matthaus B, Vosmann K, Pham LQ, Aitzetmuller K, 2003. FA an tocopherol composition of Vietnamese oil seeds, J. Am. Oil Chem. Soc. 80: 1013-1020.

Nookabkaew S, Rangkadilok N, Satayavivad J, 2006. Determination of trace elements in herbal tea products and their infusions consumed in Thailand. Journal of Agricultural and Food Chemistry. 54: 6939-6944.

Ozdemir S, Kilinc E, Poli A, Nicolaus B, Guven K, 2009. Biosorption of $\mathrm{Cd}, \mathrm{Cu}, \mathrm{Ni}, \mathrm{Mn}$ and $\mathrm{Zn}$ from aqueous solutions by thermophilic bacteria, Geobacillus toebii sub. sp. decanicus and Geobacillus thermoleovorans sub. sp. stromboliensis: Equilibrium, kinetic and thermodynamic studies, Chemical Engineering Journal, 152: 195-206.

Oztekin M, Euphorbia L, Güner A, Aslan S, Ekim T, Vural M, Babac MT, 2012. Editors. A checklist of the flora of Turkey (vascular plants). Istanbul: Nezahat Gökyiğit Botanic Garden (NGBB), ANG Foundation and Flora Research Society, p: 414-424.

Ozhatay N, Kultur S, Gurdal MB, 2011. Check-list of addiotional taxa to the supplement flora of Turkey V. Turk J Bot 35: 1-36.

Robson N.K.B, 1988. Hypericum in Flora of Turkey and the East Aegean Islands, Vol 10 ed. by Davis PH, Edinburg University Press, Edinburgh, pp: 96-103.
Saglam C. 2013. Heavy Metal Accumulation in the Edible Parts of Some Cultivated Plants and Media Samples from a Volcanic Region in Southern Turkey. Ekoloji 22(86): 1-8.

Tokalioglu S, 2012. Determination of trace elements in commonly consumed medicinal herbs by ICP-MS and multivariate analysis. Food Chemistry, 134(4): 2504-2508.

Turkoglu I, 2000. The investigation on the ethnobotanical valued taxa growing around Elazig province, $\mathrm{PhD}$, Graduate School of Natural and Applied Science, Department of Biology University of Firat.

Varhan Orala E, Tokul-Olmez Ö, Yener I, Firat M, Tunay Z, Terzioglu P, Aydin F, Ozturk M, Ertas A, 2018. Trace Elemental Analysis of Allium Species by Inductively Coupled Plasma-Mass Spectrometry (ICP-MS) with Multivariate Chemometrics. Analytical Letters, DOI: 10.1080/00032719.2018.1460376.

Webester G. 1994. Annals of the Missouri Botanical Garden: Systematic of the Euphorbiaceae; Missouri Botanical Garden Press: St. Louis, MO, USA, V. 81, pp. 33-144. 